\title{
Effectiveness of acidizing geothermal wells in the South German Molasse Basin
}

\author{
S. Schumacher and R. Schulz \\ Leibniz Institute for Applied Geophysics, Stilleweg 2, 30655 Hanover, Germany \\ Correspondence to: S. Schumacher (sandra.schumacher@liag-hannover.de)
}

Received: 7 May 2013 - Revised: 9 September 2013 - Accepted: 2 October 2013 - Published: 22 October 2013

\begin{abstract}
In Germany, many hydro-geothermal plants have been constructed in recent years, primarily in the region of Munich. As the host formation here mainly consists of carbonates, nearly all recently drilled wells have been acidized in order to improve the well yield. In this study, the effectiveness of these acid treatments is analyzed with respect to the amount of acid used and the number of acid treatments carried out per well. The results show that the first acid treatment has the largest effect, while subsequent acidizing improves the well only marginally. Data also indicate that continued acidizing can lead to degradation of the well. These findings may not only be important for geothermal installations in Germany but also for projects, for example, in Austria, France or China where geothermal energy is produced from carbonate formations as well.
\end{abstract}

\section{Introduction}

\subsection{Geothermal energy in Germany}

The growing need for energy and the rising prices of conventional energy sources such as oil, gas and coal have led to increased interest and investment in environmentally friendly, renewable energy in Germany. One such renewable resource is geothermal energy, which, compared to other more widespread resources such as wind or solar energy, has the tremendous advantage of being able to deliver heat and electrical energy independent of weather conditions and time of day.

In Germany, large geothermal plants require the use of deep geothermal energy, which so far has only been used in the form of hydro-geothermal energy (Schellschmidt et al., 2010). For this kind of energy, certain requirements have to be fulfilled, such as the existence of an aquifer of hot water. Hence, the generation of hydro-geothermal energy in Germany is mainly confined to three areas: the North German Basin, the Upper Rhine Graben and the South German Molasse Basin. The Molasse Basin (specifically the region of Munich) has become the center of geothermal energy production in Germany within the last few years due to favorable geological conditions.

\subsection{Geological setting}

In the Molasse Basin, hot water can be found in the stratigraphic unit of the Malm aquifer (Upper Jurassic). The sedimentary layers of the karstic Malm aquifer primarily consist of carbonate rocks, namely small-pored white limestones as well as fine-to-coarse crystalline dolomites (e.g., Wolfgramm et al., 2007). For the well Pullach Th2, pure limestones as well as limestone layers that contain clay in varying degrees have been described (Böhm et al., 2010), while Reinhold (1998) identifies oolitic platform sands with associated mounts of microbe-siliceous sponges in the Upper Jurassic of the Swabian Alb (Swabian facies). These variations in material can be explained by the different facies that can be encountered in the Malm aquifer. Facies found in the Malm aquifer encompass the Swabian, the Franconian, and the Helvetic facies.

The Helvetic facies developed under distal conditions and as a consequence contains not only carbonates but also a significant amount of marls (Meyer and SchmidtKaler, 1996). Therefore, it exhibits only very small transmissivities (Villinger, 1988; Bayerisches Staatsministerium für Wirtschaft, Infrastruktur, Verkehr und Technologie, 2010). Although the Helvetic facies is restricted to the southwestern part of the basin, small transmissivities are not restricted to the Helvetic facies itself but are also found in areas adjacent 


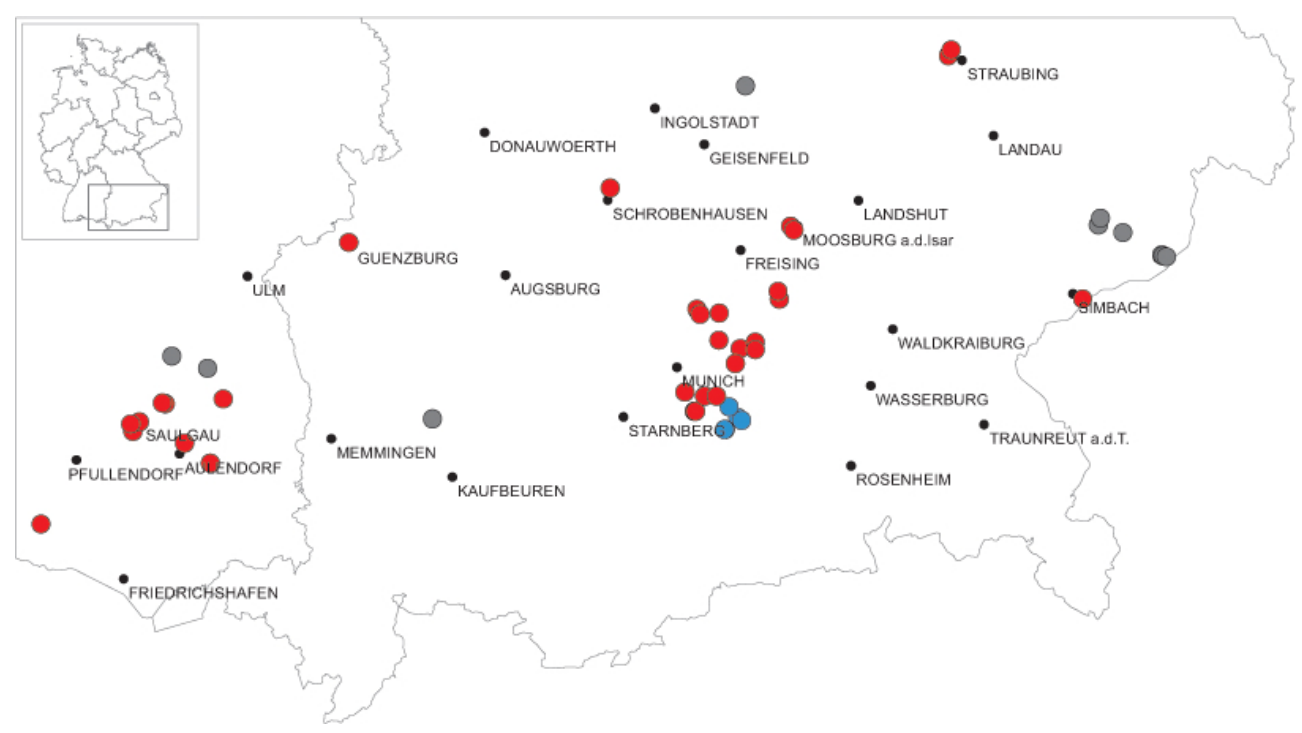

Figure 1. A map of southern Germany and geothermal installations within the Malm aquifer. Main uses are district heating (red dots), power generation (blue dots), and spas (gray dots).

to it (Stober and Villinger, 1997), which can be explained by a lack of karstification (Villinger, 1997).

The Franconian facies, found in the region of Munich, developed in a shelf environment. It contains basin facies and reef facies. While the basin facies consists of banked limestones, which were deposited in shallow waters between reefs, the carbonates of the reef facies are built up by reef detritus. Thus, the matrix porosity of the reef facies tends to be higher than that of the other facies. As a result, recrystallization of limestone into dolomite primarily takes place in the reef facies (e.g., Bausch, 1963). Dolomites are characterized by a predominantly good porosity caused by the reduction in volume due to the dolomitization of limestone (Koch, 1997), which can result in an increase in porosity by up to $13 \%$ (Böhm et al., 2011). Therefore, the reef facies in the Molasse Basin is of special interest for the planning of geothermal projects.

In addition to matrix porosity, pathways for fluid flow that have been created by karstification play a dominant role within the Malm aquifer. As a result, transmissivity is higher in the north of the basin than in the south, since rocks in the north underwent a higher rate of karstification than those in the south, where the transmissivity depends mainly on the matrix porosity of the carbonates (Koch and Sobott, 2005) and on fissures (Wolfgramm et al., 2009). Analysis of pump tests shows that transmissivities within the Malm aquifer vary by more than seven orders of magnitude (Birner et al., 2012). However, in the region of Munich, which is of special interest for this study due to the high number of geothermal wells in this area, transmissivities change by only two orders of magnitude (Birner et al., 2012).

It is also important to note that the water within the Malm aquifer shows only low mineralization (e.g., Prestel, 1990;
Wolfgramm and Seibt, 2008) despite the fact that this water has been buried to significant depths for long periods. Prestel (1990), for example, gives an age of 6700 to $10400 \mathrm{yr}$ for water encountered in the well Saulgau GB3 (for approximate location see Fig. 1, "Saulgau"), dating it to the Holocene. Bertleff and Watzel (2002) state that water in the basin's center is of Pleistocene age. In general, water tends to be younger toward the borders of the basin, but it has been found that the mineral load is low even at the center. Because of this, water within the Malm aquifer is a perfect repository for hydrogeothermal energy use.

\subsection{Technical details}

The geologic setting is important for the exploitation of geothermal energy in the Molasse Basin as not only is a high transmissivity needed in order to operate geothermal power plants economically, but high temperatures are also essential. As a general trend, it can be observed that with increasing depth of the Malm aquifer to the south, temperatures found within this layer also increase. This, however, is contrary to the behavior of the transmissivity, which tends to decrease to the south (Birner et al., 2012).

In the region of Munich, both parameters were assumed to exhibit values suitable for the exploitation of geothermal energy for district heating and/or electricity generation. Therefore, in recent years many geothermal plants have been constructed in this area. In order to increase the yield of the wells and therefore their economic efficiency, acidizing has been performed on nearly all of these wells. The primary acid used was hydrochloric acid in varying dilutions, but in some cases small amounts of citric and acetic acid were also used 
as admixing. In this work the effectiveness of these acid treatments has been analyzed based on data from 17 wells.

\subsection{Data origin}

In Germany, operators of geothermal plants are legally obligated to pass on information about stimulation procedures and pump tests to the responsible state geological survey. However, they are not required to go into detail or to give access to the original measurements. In general, the results of pump test analyses done by service companies are reported. Depending on the service company, these reports include details about the duration of the stimulation measure or the part of the well acidized, but often only the bare minimum (such as flow rate and specific capacity, i.e., flow rate divided by drawdown) is included.

As part of the research project "Geothermal Information System for Germany" (GeotIS), access to the information of the state geological surveys was granted, which enabled this metaanalysis of acidizing data. However, this meant that none of the original pump test measurements and only limited information about their analysis was available. Therefore, this paper deals only with the most basic data, which are routinely acquired by operators of geothermal plants. This has the advantage that future geothermal projects do not need to deviate from standard procedures in data acquisition and analysis in order to use the insights gained from this work.

\section{Theory of laminar and turbulent flow}

Fluid flow into a well is defined by Darcy's law.

$Q=k \cdot A \cdot i$

with $Q$ being the flow rate $\left[\mathrm{m}^{3} \mathrm{~s}^{-1}\right], k$ the coefficient of permeability or hydraulic conductivity $\left[\mathrm{m} \mathrm{s}^{-1}\right], A$ the surface area through which the fluid passes $\left[\mathrm{m}^{2}\right]$, and $i$ is the hydraulic gradient [1]. Under the assumption that the water enters the well perpendicular to the well's axis through parts of the uncemented regions of the borehole, Eq. (1) can be rewritten as

$Q=2 \pi r H k \frac{\mathrm{d} h}{\mathrm{~d} l}$,

where $r$ is the radius of the borehole [m], $H$ the thickness of the aquifer [m], and $\mathrm{d} h / \mathrm{d} l$ is the gradient of the water table or piezometric surface [1] (Hamill and Bell, 1986; Hölting and Coldewey, 2009). It is therefore apparent that the flow rate depends linearly on the hydraulic conductivity of the surrounding rock. In the case of a karst aquifer, such as the Malm aquifer, the hydraulic conductivity of the immediate surroundings may be small due to a lack of fissures and fractures, and therefore impeding a high flow rate. The overall hydraulic conductivity of the aquifer, however, may be comparatively high and well-suited for geothermal exploitation. Thus, the idea of acidizing is to improve the connection of the well to fissures and fractures in its immediate surroundings, and to widen those in order to enhance the well's flow rate.

The theory of fluid dynamics has shown that the transition from laminar to turbulent flow in a pipe occurs at a Reynolds number $R e$ between about 2200 (Turcotte and Schubert, 2002) and 2300 (Schlichting and Gersten, 2001), with $R e$ [1] being defined as

$R e=\frac{\rho \cdot v \cdot D}{\mu}$,

where $\rho$ is the fluid's density $\left[\mathrm{kg} \mathrm{m}^{-3}\right], D$ the diameter of the borehole [m], and $\mu$ the fluid's dynamic viscosity [Pa s]. The critical velocity for the onset of turbulence for boreholes considered in this study can be calculated to be in the range of about 0.002 to $0.010 \mathrm{~m} \mathrm{~s}^{-1}$. This is far below the velocity of about $1.4 \mathrm{~m} \mathrm{~s}^{-1}$ that is obtained for a flow rate of $50 \mathrm{~L} \mathrm{~s}^{-1}$, which is a typical flow rate for the wells considered in this analysis. Fully developed turbulent flow can be assumed to take place for $R e>5000$ (Spurk, 2006). As the Reynolds numbers for all wells are larger than 400000 , it can be concluded that all wells operate within the fully turbulent regime.

Pump tests are a combination of an aquifer test and a well test. Flow within the aquifer is assumed to be laminar, while it is assumed to be turbulent within the well and its immediate surroundings. In previous modeling of the Malm aquifer in the region of Munich, it has been shown that the pressure conditions within the aquifer can be simulated using a porous matrix with laminar flow instead of a karst model (Bartels et al., 2012; Bartels and Wenderoth, 2012), which can also exhibit turbulent flow. The porous matrix model has been calibrated against well test data as well as data from operating geothermal plants, and a good correlation between measured and modeled data has been achieved. Thus, the assumption of laminar flow within the Malm aquifer for large-scale considerations seems justified. The assumption of turbulent flow within the well and its surroundings has been shown above to be correct for the wells considered in this analysis. Therefore, the equation proposed by, for example, Jacob (1947) and Hamill and Bell (1986) for the drawdown in the well can describe this behavior mathematically:

$s=B Q+C Q^{2}$,

where $s$ is the drawdown $[\mathrm{m}], Q$ the flow rate $\left[\mathrm{m}^{3} \mathrm{~s}^{-1}\right]$, and $B$ and $C$ coefficients with units of $\left[\mathrm{s} \mathrm{m}^{-2}\right]$ and $\left[\mathrm{s}^{2} \mathrm{~m}^{-5}\right]$, respectively. The drawdown can be described either by the height difference of the water column in the well or by the pressure difference that is caused by changes in water column height and that is measured by a pressure gauge within the well. In the latter case, the unit of drawdown changes to [MPa], with the units of $B$ and $C$ changing accordingly. The term $B Q$ describes the aquifer loss, while $C Q^{2}$ is the well loss. However, this equation has been derived from experimental data, 
and Rorabaugh (1953) argues that the exponent of $C Q^{2}$ can vary as it depends on the well efficiency.

In this case, the well loss can be more generally expressed as $C Q^{p}$, where $p$ is the exponent as determined by well efficiency, and varies between 1.5 and 3.5 . The specific capacity $S_{\mathrm{c}}$ in $\left[\mathrm{m}^{2} \mathrm{~s}^{-1}\right]$ or $\left[\mathrm{m}^{3} \mathrm{~s}^{-1} \mathrm{MPa}^{-1}\right]$ can then be determined by the following equation:

$S_{\mathrm{c}}=\frac{Q}{s}=\frac{1}{B+C Q^{(p-1)}}$.

It becomes apparent that the specific capacity of a well decreases with increasing flow rate independent of the mathematical approach used for the well loss. The reason for this is that the water loses kinetic energy due to friction that already occurs in the laminar regime. Turbulence introduces yet another element into the analysis of the fluid flow. As long as the well operates within the laminar regime, the viscosity of the water mainly depends on its temperature. In the turbulent regime, however, eddies within the water lead to the so-called "eddy viscosity", which describes the apparently higher viscosity because of a transfer of kinetic energy to internal energy of the fluid (Schlichting and Gersten, 2001). Because of this and other smaller effects, turbulence introduces more complexity into the calculations and has to be considered in separate terms.

\section{Data set and normalization}

For many wells acidizing took place in several steps with interposed pump tests. Moreover, a large number of pump tests were carried out as step drawdown tests. The result of this combination can be seen in Fig. 2, where all available data for step drawdown tests are displayed.

Figure 2 shows that the specific capacity is reduced if the flow rate is increased. In this and all following figures, the same symbols and the same well numbers signify the same borehole, while the same colors are indicators of the same acidizing step. The reduction of the specific capacity occurs because a higher flow rate also means a higher velocity of the water within the well and its surroundings, which leads to turbulence for all wells considered in this analysis.

The decrease in specific capacity makes it harder to compare the results of pump tests. Most pump tests were done at different flow rates (see Fig. 2), so due to the effect described above, their results cannot be directly compared, but need to be normalized. In order to achieve this, a linear equation was established for each borehole and acidizing step, describing the decrease in specific capacity with increasing flow rate. The validity of assuming a linear equation is shown in Fig. 2, where especially the long-time pump tests indicate a linear decrease of the specific capacity for the range of flow rates analyzed. For the area of Munich, 23 data sets were available, which contained more than one pump test per acidizing step and for which a linear equation could be found. The resulting slopes of these equations were then averaged so as to

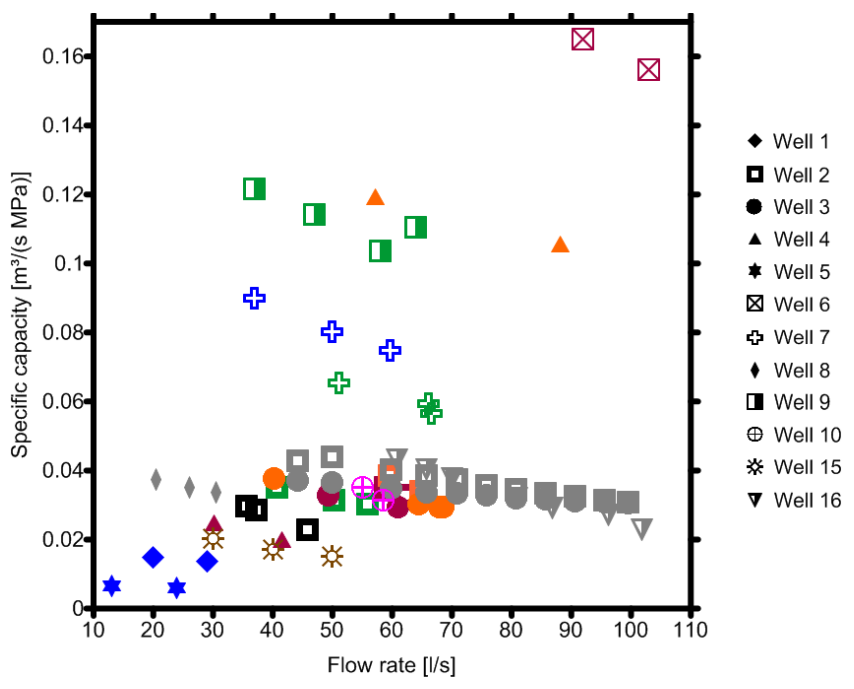

Figure 2. Data used to calculate linear equation for the reduction of the specific capacity with increasing flow rate. Colors indicate the time when the pump tests were performed: before first acid treatment (black), after first acid treatment (green), after second acid treatment (blue), after third acid treatment (red), after fourth acid treatment (orange), after fifth acid treatment (pink), after sixth acid treatment (brown), and long-time pump tests (gray).

use a common value for all further calculations. The resulting linear equation for normalization is

$S_{\mathrm{c}_{\text {norm }}}=-0.438 \mathrm{MPa}^{-1} \cdot Q+y$,

where $S_{\mathrm{c}_{\text {norm }}}$ is the normalized specific capacity and $y$ the intercept with the ordinate, which has been determined for each acidizing step and borehole beforehand. In principle, it would have been better if each borehole and acidizing step were normalized based on its own linear equation. This, however, was not feasible due to lack of data since for some boreholes and acidizing steps the pump test was only carried out for one flow rate. As a result, no linear equation could be obtained for four boreholes (boreholes 11, 12, 13 and 14). Thus, an averaged slope was used for normalization in order to use a standardized method for all boreholes and to be able to increase the number of boreholes analyzed. The variance $\sigma^{2}$ of the slope of Eq. (6) is 0.066. Even though using an averaged slope leads to some minor distortion regarding the absolute values of specific capacity, it does not influence the values for the relative improvement of the specific capacity from one acidizing step to the next, which are of far more interest for this study.

Since for most boreholes and acidizing steps more than one specific capacity value was obtained from pump tests, the existing specific capacity and flow rate values of each acidizing step and each borehole were averaged to generate mean values. The resulting mean values for each acidizing step then served as starting points for the normalization. The result of this normalization can be seen in Fig. 3 . 


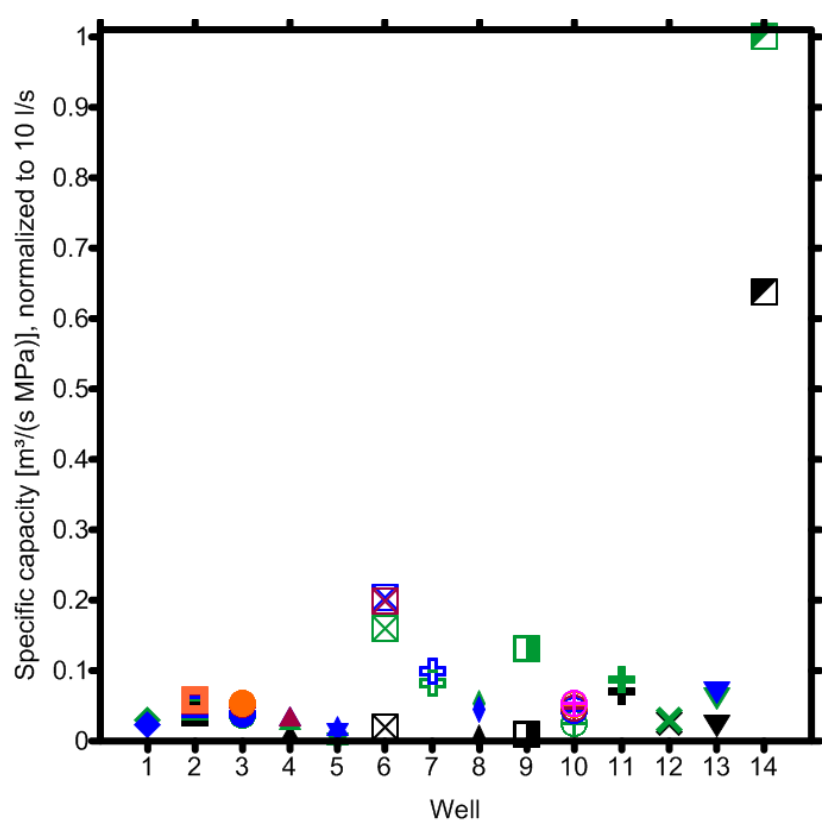

Figure 3. Specific capacity for different wells before and after acidizing (for details see Fig. 4). Colors indicate the time when the pump tests were performed: before first acid treatment (black), after first acid treatment (green), after second acid treatment (blue), after third acid treatment (red), after fourth acid treatment (orange), and after fifth acid treatment (pink).

The results of all pump tests were normalized to a flow rate of $10 \mathrm{~L} \mathrm{~s}^{-1}$ by using Eq. (6). A rate of $10 \mathrm{~L} \mathrm{~s}^{-1}$ is very low, much lower than the usual flow rate for most of the wells. It was chosen for two reasons. First of all, extrapolation to higher flow rates of, for example, $100 \mathrm{~L} \mathrm{~s}^{-1}$ can be problematic as it is unclear up to which flow rate the inferred linear equation holds true. As discussed above (Sect. 2), high flow rates are connected to the turbulent regime. Turbulence, however, implies that the exponential term of Eq. (5) comes to bear and, subsequently, the linear equation can no longer be used. The second reason for using a rather low value was the fact that some wells exhibit very low specific capacities. Extrapolating the linear equation to high flow rates would lead to negative values for these wells. As this is physically infeasible, it had to be avoided. Thus, a flow rate of $10 \mathrm{~L} \mathrm{~s}^{-1}$ met all requirements with regard to validity of extrapolation.

\section{Results}

In Fig. 3 the results of 14 boreholes are displayed, for which data for more than one acidizing step could be obtained. It should be noted that two boreholes of Fig. 2, wells 15 and 16 , are not part of the group of these 14 boreholes for which all subsequent calculations and considerations are done.

In Fig. 3 some wells (namely wells 6, 9 and 14) exhibit an enormous increase in the specific capacity due to acidizing, while for the majority of wells acidizing only led to a

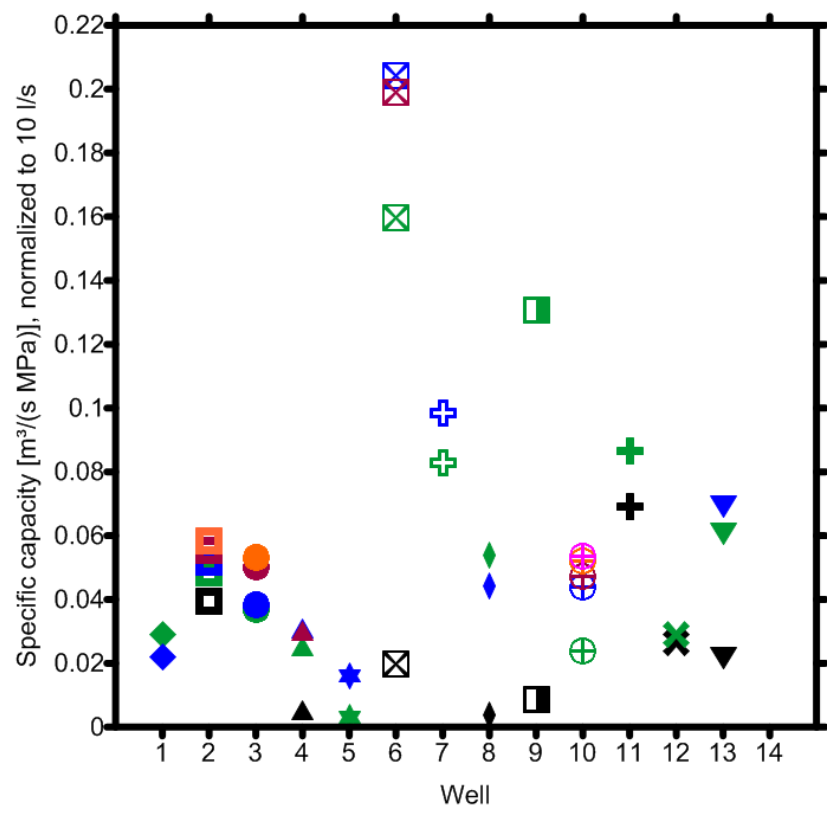

Figure 4. Specific capacity for different wells before and after acidizing (extract of Fig. 3). Colors indicate the time when the pump tests were performed: before first acid treatment (black), after first acid treatment (green), after second acid treatment (blue), after third acid treatment (red), after fourth acid treatment (orange), and after fifth acid treatment (pink).

marginal improvement. This latter observation becomes especially apparent in Fig. 4, which displays the same data as Fig. 3 with the exception of data for well 14 . Thus, it is possible to show the small increases in specific capacity for all other wells in more detail. The fact that acidizing has only a small impact on some wells is especially pronounced for wells 2, 3 and 10. For these wells there are plenty of data for different acidizing steps. All these data show that the effect of the acidizing is diminished with increasing number of acidizing steps.

However, the improvement that is generated by acidizing depends not only on the number of acidizing steps, but also on the amount of acid used for each step. For some wells, the amount used was kept constant for different acidizing steps but some wells exhibit great variations (Table 1). In order to test how far the improvement of the specific capacity correlates with the amount of acid used, the specific capacity improvement was normalized to the amount of acid $(15 \% \mathrm{HCl})$ used. The results of this are shown in Fig. 5. In this figure, the changes in the specific capacity after an acidizing step, as compared to before the acidizing step, are displayed. Thus, only the relative improvement and not the absolute improvement is shown. This approach is used for all further comparisons. As could be expected, the improvement of the specific capacity is large for well 14 even after normalization to the amount of acid used. Moreover, it is again made evident that the effectiveness of the acidizing is reduced with every 


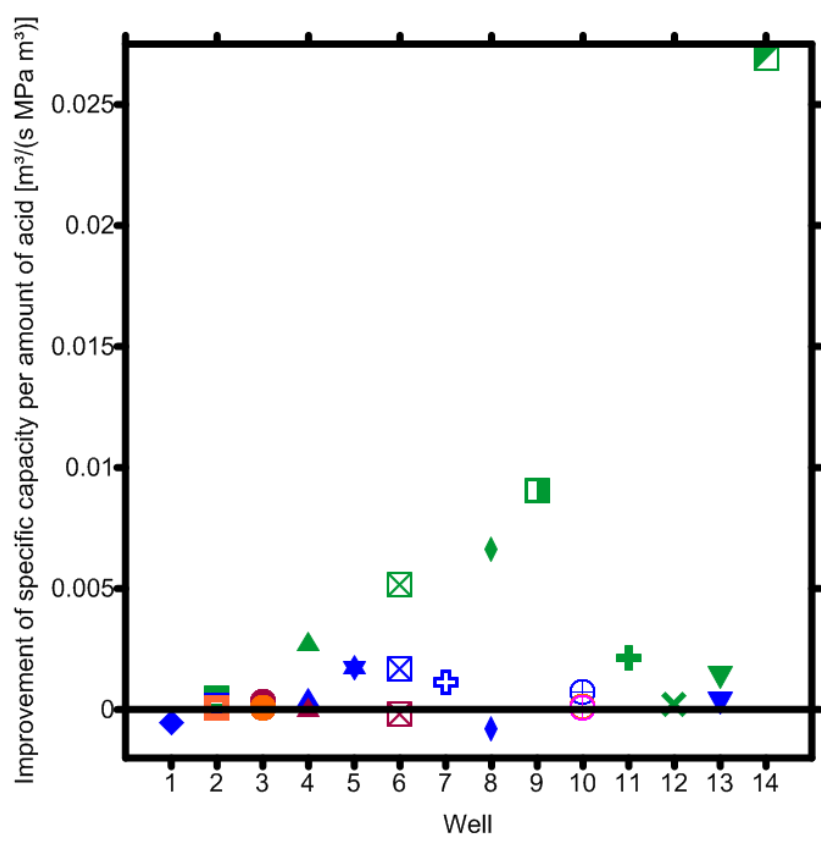

Figure 5. Improvement of the specific capacity normalized to the amount of acid used (for details see Fig. 7). Colors indicate the acidizing step that causes the improvement: first (green), second (blue), third (red), fourth (orange), and fifth (pink).

further acidizing undertaken. Thus, the trend that could already be observed in Fig. 4 holds true even if the amount of acid used is taken into account.

It becomes even clearer in Fig. 6, where the increase in specific capacity per acidizing step has been plotted for two wells. Wells 2 and 10 are those that exhibit the highest number of acidizing steps undertaken and monitored, and they therefore provide the best database. However, even for those two wells the data are not perfect. For well 10 the specific capacity of the unstimulated well has not been measured, and thus the improvement due to the first acid treatment is unknown. Still, the trend of initially high gains due to acidizing with subsequent stagnation at low levels is apparent.

Except for well 14, there are some other wells that exhibit a significant improvement of the specific capacity. These are primarily wells that already displayed a large improvement in Fig. 4; however, well 8 is an exception to this rule. For this well, the first acid treatment was extremely effective, while the second acid treatment shows a surprising result: the specific capacity decreased. Thus, the second acid treatment worsened the well compared to the situation after the first acid treatment. If this were the only well for which such an observation could be made, an error in the recorded pump test data or a mistake in its analysis would have been a likely explanation for this unexpected result. However, three other wells, namely wells 1, 4 and 6, exhibit a similar behavior. This can be observed in Fig. 7, which is an extract of Fig. 5 and shows the results in more detail.

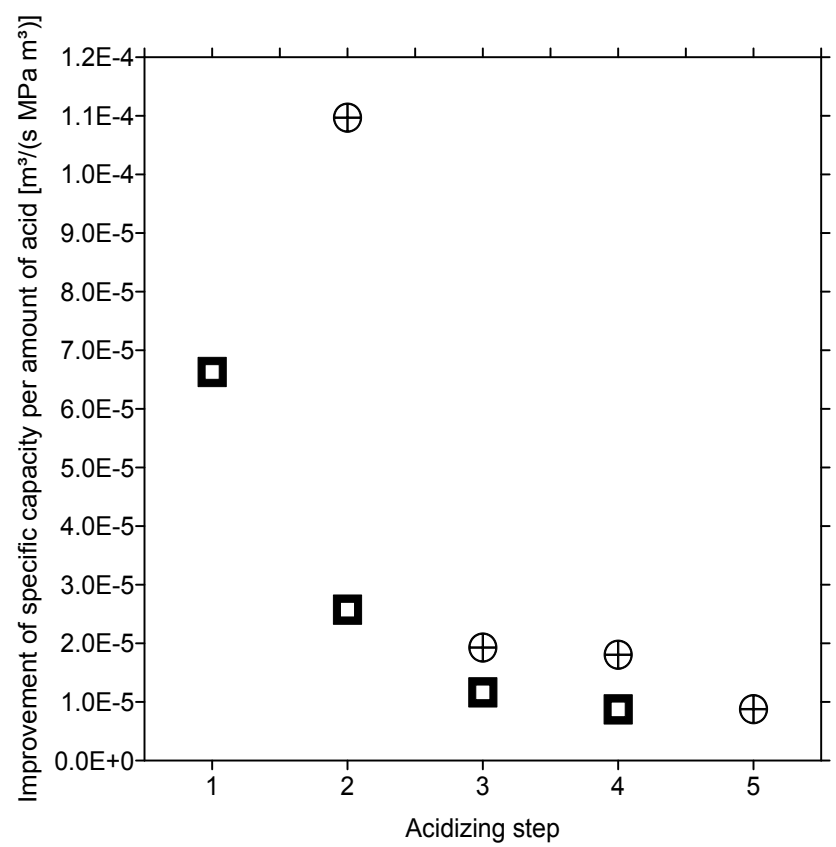

Figure 6. Improvement of the specific capacity normalized to the amount of acid used for two wells: well 2 (black squares) and well 10 (black crossed circles).

In this figure it is very obvious that for some wells continued acidizing results in a reduction of the specific capacity. The first and maybe second acid treatment lead to an improvement of the specific capacity, but subsequent acidizing worsens the results. In all cases in which the initial specific capacity is known, acidizing was successful (i.e., the specific capacity after the last acidizing step was higher than initially), even for wells that show a reduction after the first or second acidizing step. However, in some cases the result could have been better if less acid treatments had been applied.

In Fig. 8 the improvement of the specific capacity in percent is shown. Again it is normalized to the amount of acid used, and in this case also to a flow rate of $10 \mathrm{~L} \mathrm{~s}^{-1}$. The latter normalization is necessary as percentages are based on absolute values and therefore need to have the same reference value if they are to be compared.

As in all other figures, the improvement is not related to the initial specific capacity but to that of the acidizing step before. In the case of percentages, this means that some wells exhibit extremely high improvements of more than $25 \%$ per $\mathrm{m}^{3}$ acid. However, in general, these wells were suffering from very low initial specific capacities so that even moderate improvements translated into high percentage gains.

Nevertheless, it is noteworthy that wells that show a reduction in specific capacity with consecutive acidizing (wells 4, 6 and 8) are among the group of wells that show high initial percentage gains. Unfortunately, there are no data for wells 1,5 or 9 , which could indicate if this is a pattern or a mere 
Table 1. Listing of the different sorts, concentrations and amounts of acids used for acidizing.

\begin{tabular}{|c|c|c|c|}
\hline Well number & Acidizing step & Acid & Amount \\
\hline \multirow[t]{2}{*}{1} & 1 & $15 \% \mathrm{HCl}$ & $90 \mathrm{~m}^{3}$ \\
\hline & 2 & $15 \% \mathrm{HCl}$ & $90 \mathrm{~m}^{3}$ \\
\hline \multirow[t]{4}{*}{2} & 1 & $20 \% \mathrm{HCl}$ & $100 \mathrm{~m}^{3}$ \\
\hline & 2 & $15 \% \mathrm{HCl}, 3 \% \mathrm{C}_{2} \mathrm{H}_{4} \mathrm{O}_{2}$ & $130 \mathrm{~m}^{3}$ \\
\hline & 3 & $15 \% \mathrm{HCl}$ & $320 \mathrm{~m}^{3}$ \\
\hline & 4 & $15 \% \mathrm{HCl}, 6 \% \mathrm{C}_{2} \mathrm{H}_{4} \mathrm{O}_{2}, 1 \% \mathrm{C}_{6} \mathrm{H}_{8} \mathrm{O}_{7}$ & $320 \mathrm{~m}^{3}$ \\
\hline \multirow[t]{4}{*}{3} & 1 & $20 \% \mathrm{HCl}$ & $100 \mathrm{~m}^{3}$ \\
\hline & 2 & $20 \% \mathrm{HCl}$ & $150 \mathrm{~m}^{3}$ \\
\hline & 3 & $20 \% \mathrm{HCl}$ & $200 \mathrm{~m}^{3}$ \\
\hline & 4 & $20 \% \mathrm{HCl}$ & $200 \mathrm{~m}^{3}$ \\
\hline \multirow[t]{3}{*}{4} & 1 & $7.5 \% \mathrm{HCl}$ & $100 \mathrm{~m}^{3}$ \\
\hline & 2 & $7.5 \% \mathrm{HCl}$ & $200 \mathrm{~m}^{3}$ \\
\hline & 3 & $7.5 \% \mathrm{HCl}$ & $200 \mathrm{~m}^{3}$ \\
\hline \multirow[t]{2}{*}{5} & 1 & $15 \% \mathrm{HCl}$ & $50 \mathrm{~m}^{3}$ \\
\hline & 2 & $7.5 \% \mathrm{HCl}$ & $100 \mathrm{~m}^{3}$ \\
\hline \multirow[t]{3}{*}{6} & 1 & $15 \% \mathrm{HCl}$ & $180 \mathrm{~m}^{3}$ \\
\hline & 2 & $15 \% \mathrm{HCl}$ & $180 \mathrm{~m}^{3}$ \\
\hline & 3 & $15 \% \mathrm{HCl}$ & $180 \mathrm{~m}^{3}$ \\
\hline \multirow[t]{2}{*}{7} & 1 & $7.5 \% \mathrm{HCl}$ & $100 \mathrm{~m}^{3}$ \\
\hline & 2 & $7.5 \% \mathrm{HCl}$ & $190 \mathrm{~m}^{3}$ \\
\hline \multirow[t]{2}{*}{8} & 1 & $15 \% \mathrm{HCl}$ & $50 \mathrm{~m}^{3}$ \\
\hline & 2 & $15 \% \mathrm{HCl}$ & $80 \mathrm{~m}^{3}$ \\
\hline 9 & 1 & $7.5 \% \mathrm{HCl}$ & $180 \mathrm{~m}^{3}$ \\
\hline \multirow[t]{5}{*}{10} & 1 & $15 \% \mathrm{HCl}$ & $180 \mathrm{~m}^{3}$ \\
\hline & 2 & $15 \% \mathrm{HCl}$ & $180 \mathrm{~m}^{3}$ \\
\hline & 3 & $15 \% \mathrm{HCl}$ & $180 \mathrm{~m}^{3}$ \\
\hline & 4 & $15 \% \mathrm{HCl}$ & $270 \mathrm{~m}^{3}$ \\
\hline & 5 & $15 \% \mathrm{HCl}$ & $180 \mathrm{~m}^{3}$ \\
\hline 11 & 1 & $15 \% \mathrm{HCl}, 6 \% \mathrm{C}_{2} \mathrm{H}_{4} \mathrm{O}_{2}$ & $50 \mathrm{~m}^{3}$ \\
\hline 12 & 1 & $15 \% \mathrm{HCl}$ & $75 \mathrm{~m}^{3}$ \\
\hline \multirow[t]{2}{*}{13} & 1 & $15 \% \mathrm{HCl}$ & $200 \mathrm{~m}^{3}$ \\
\hline & 2 & $15 \% \mathrm{HCl}$ & $200 \mathrm{~m}^{3}$ \\
\hline 14 & 1 & $7.5 \% \mathrm{HCl}$ & $180 \mathrm{~m}^{3}$ \\
\hline
\end{tabular}

coincidence. Either no pump test was performed before the first acid treatment (wells 1 and 5), or only one acidizing step was carried out (well 9).

The temperature dependence of the reaction of hydrochloric acid with limestone has also been analyzed. No clear correlation between temperature and effectiveness of acidizing could be observed. Therefore, this effect has not been taken into account for the comparison of wells in Figs. 3 to 8 (see Sect. 5.3).

\section{Discussion}

The analysis of data from 14 wells in the region of Munich shows that acidizing with hydrochloric acid can significantly improve a well drilled into carbonate rock. The improvement can be well over $10 \%$ per $\mathrm{m}^{3}$ of $15 \% \mathrm{HCl}$ used. However, the data also indicate that the increases in specific capacity result primarily from the first acid treatment. All subsequent acidizing - especially everything above two treatments - does not have a significant impact any more. This holds true even for 


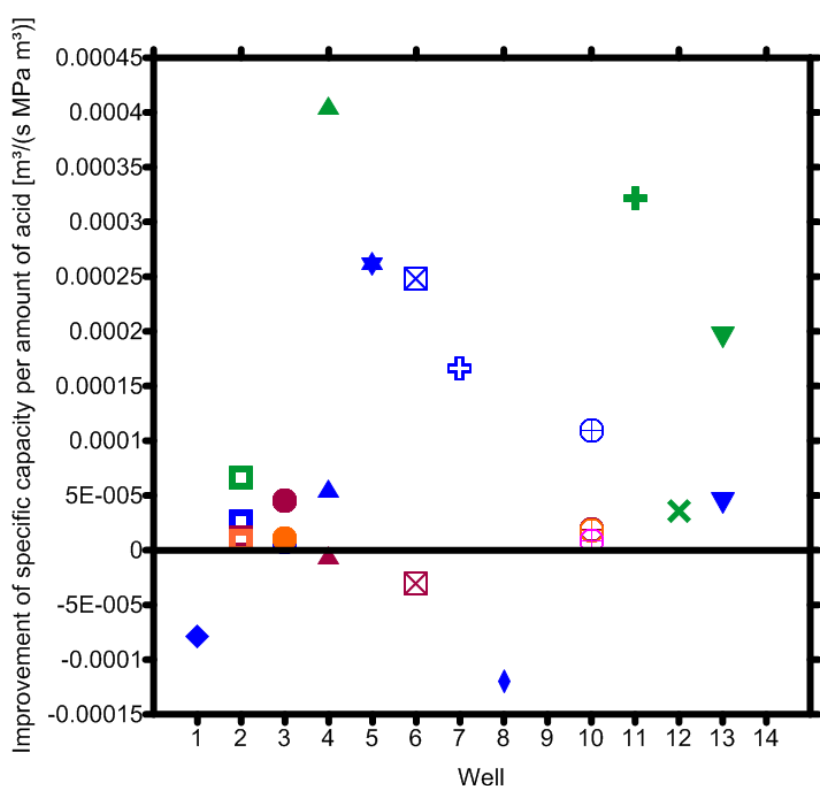

Figure 7. Improvement of the specific capacity normalized to the amount of acid used (extract of Fig. 5). Colors indicate the acidizing step that causes the improvement: first (green), second (blue), third (red), fourth (orange), and fifth (pink).

wells for which an initial pump test was performed in which the well should have been pumped clean of drilling residue. The results of the first acid treatment indicate that these initial cleaning measures did not have the desired effect and that only acidizing can effectively remove fine material from the well's walls. Thus, the primary effect of acidizing is to clean the well and not to improve the reservoir by widening already existing fissures or generating new pathways for water to circulate. As a consequence, only the first and sometimes second acid treatment have a significant impact on the specific capacity.

\subsection{Amount of acid}

The amounts of acid used are well below the recommended values for the acidizing of wells in carbonate rock that have been published by Gdanski (2005). This author gives about $1 \mathrm{~m}^{3}$ of $15 \% \mathrm{HCl}$ per meter of acidized borehole as a rule of thumb for matrix acidizing. In such a case, the injection pressure of the acid is below the fracture pressure of the rock. If acid fracturing is assumed (i.e., the rock is first fractured with high pressure and then treated with acid), even higher amounts of acid are recommended. Thus, the amounts actually used (see Table 1) were always on the lower side of acid volumes suggested for acidizing. However, it has to be clearly stated that acidizing of the wells analyzed was performed as matrix acidizing and not as acid fracturing even though matrix acidizing of the karstified Malm aquifer might have required larger amounts of acid than matrix acidizing of, for example, tight carbonates.

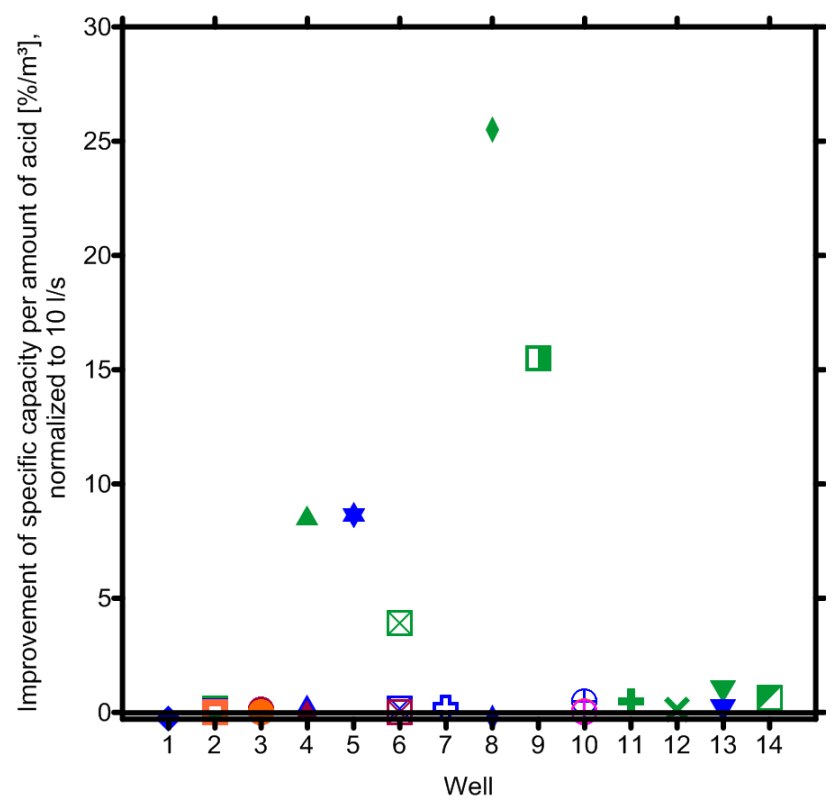

Figure 8. Improvement of the specific capacity normalized to the amount of acid used and a flow rate of $10 \mathrm{Ls}^{-1}$. Colors indicate the acidizing step that causes the improvement: first (green), second (blue), third (red), fourth (orange), and fifth (pink).

\subsection{Injection rate}

On the other hand, it can be argued that geothermal wells do not require the same amount of acidizing as oil wells, since water is less viscous than oil and can therefore far better percolate through small fractures than oil. As a consequence, geothermal wells might rely more heavily on the penetration depth of the acid than on the widening effect of existing fractures. The penetration depth of the acid depends primarily on the injection rate as a higher injection rate means higher pressure within the well. So for a given porosity, a higher injection rate means that the acid will penetrate deeper into the matrix before it is spent. As a rule of thumb, for matrix acidizing conditions Gdanski $(2001,2005)$ gives about 0.1 barrel $\mathrm{min}^{-1}$ for each foot of penetration depth, which translates into about $0.7 \mathrm{~L} \mathrm{~s}^{-1}$ per meter of penetration depth. Given the known pump rates for some of the analyzed wells, penetration depths according to this rule should have been about 10 to $40 \mathrm{~m}$. It is therefore obvious that no wide-ranging effects can be expected, but that merely the immediate surroundings of the well are treated. This adds to the observation that the effect of acidizing is strongest for the first treatment, which primarily removes the damage resulting from the drilling process in the immediate surrounding of the well.

\subsection{Temperature dependence}

Another factor that can significantly influence the acidizing effect is the temperature dependence of the acid spending rate. According to, for example, Lund et al. (1974) and Allen 
and Roberts (1989), the acid spending rate increases significantly over the temperature interval encountered. Gdanski (2005), however, has shown that for the temperature range that can be encountered in the wells in the area of $\mathrm{Mu}$ nich $\left(\approx 75-145^{\circ} \mathrm{C}\right)$, the reactivity of limestone does not vary much and is moreover similar to that of dolomite. The temperature dependence within the wells of this analysis has been examined, but no clear correlation between temperature and effectiveness of acidizing could be observed. This finding is therefore in good agreement with recent research. As the temperature dependence plays a minor role, it has not been considered further.

\subsection{Reasons for well deterioration}

It is important to note that the analysis indicates that continued acidizing can worsen the well. Overall, acidizing improved all wells considered in this analysis, but for some wells the final result could have been better if the acidizing had been stopped at an earlier point in time. Moreover, this effect cannot simply be explained by faulty measurements or erroneous pump test analysis as nearly one-third of all wells show this unexpected behavior. Although two wells exhibit reductions in the specific capacity of about $3 \%$ compared to the results directly before the acid treatment in question, two wells suffer from a deterioration of about $18 \%$ and $24 \%$, respectively. Therefore, this effect is not negligible and can seriously affect the yield and thus the profitability of a well.

The reason for this unexpected behavior is unclear. It is impossible to determine a single property all the affected wells have in common, except the fact that they seem to react extremely well to the first acid treatment, if the improvement in percentage is considered. This might provide a tool for companies conducting the acidizing to estimate the risk of worsening the well, but unfortunately it does not indicate why the well reacts like this.

It can be argued that hydrochloric acid reacts with silicate minerals and causes them to increase their volume by up to five times the original size (Hamill and Bell, 1986). These particles then may cause the fine fissures within the rock to become blocked, thereby also reducing the yield of the well (Hamill and Bell, 1986). Another possibility is that continued acidizing releases insoluble particles, which then clog parts of the well.

In the case of well 4, clogging due to the precipitation of silicate minerals could be an explanation. For this well an injection test with several thousand cubic meters of freshwater during wintertime occurred between acidizing steps two and three, and directly before the decrease in specific capacity was observed. It is therefore possible that due to the injection of huge amounts of cold water the temperature inside the well was lowered significantly. At temperatures of $50^{\circ} \mathrm{C}$ or even less, the solubility of silica is already markedly lower than, for example, $100^{\circ} \mathrm{C}$ (e.g., Morey et al., 1964; Fournier and Rowe, 1977; Chigira and Watanabe, 1994), which could lead to the precipitation of silicate minerals and subsequently a blocking of fluid pathways if the well is cooled down. Another factor underlines this possibility. The specific capacity for well 4 was low even after acidizing, which indicates a rather tight rock matrix. Thus, it is conceivable that precipitation of minerals led to a significant closure of not that abundant and/or small fissures. If this was the case, the decrease in specific capacity was not the result of continued acidizing but of injections tests between acid treatments. However, this explanation can only be employed for well 4 . The decrease in specific capacity for well 6 requires an alternative explanation as no injection of huge amounts of freshwater in addition to the acid treatment happened here. For wells 1 and 8, there are no data regarding activities between acidizing steps, so based on the available information, worsening of these wells due to injection tests can also be ruled out.

As an additional explanation, the precipitation of ferric iron, which can lead to plugged fractures, is highly unlikely. The mineralization of waters from the Malm aquifer is low, and iron does not play a role (Wolfgramm and Seibt, 2008). Moreover, for one well some acidizing steps included acetic and citric acid, which react very slowly and therefore result in a low $\mathrm{pH}$ level over a prolonged period of time. Those acids chelate iron, which might exist in the aquifer, and prohibit its precipitation (Allen and Roberts, 1989). Nevertheless, the use of these acids did not improve the acidizing result. It can thus be concluded that at least iron precipitation is not a problem that has to be considered for wells in the area of Munich.

As the effect of the worsening of the specific capacity was only observed for wells that initially reacted very well to acidizing, a purely mechanical explanation is also possible. The first acid treatment might have etched sufficient flow channels into the formation to increase the specific capacity significantly. Subsequent acidizing then destroyed the pillars and posts necessary to keep these flow channels open so that the pressure of the overburden or tectonic stresses led to a partial closure of the flow channels (Allen and Roberts, 1989). However, due to lack of information it cannot be deduced which of these processes led to the observed results or if perhaps even another mechanism was responsible.

\subsection{Relevance for other geothermal areas}

Although only wells in the area of Munich have been considered for this study, the results can be transferred to other geothermal projects in different regions as the setting of geothermal wells in a karstic limestone is not unique to the South German Molasse Basin.

In the western part of Austria, the Malm aquifer also forms a huge repository for geothermal energy, which has already been tapped by several projects. It is likely that new projects will be developed in the next years for which acidizing of the wells will be considered.

For the Paris Basin especially the limestones of the Dogger have been identified as potential geothermal reservoirs 
(Ungemach et al., 2005) and are currently used by more than 30 geothermal plants with new projects in planning.

In China, waters from the Tianjin geothermal field, which consists of sandstones and fractured and karstic limestones, as well as from the Xiaotangshan geothermal field, which consists of limestones and dolomites, have been used for hundreds of years. In both areas development of new projects and the improvement of existing plants for, for example, space heating is under way (Duan et al., 2011).

Therefore, the findings of this study are not only relevant to geothermal projects planned in Germany but also to projects worldwide.

\section{Conclusions}

Acidizing of geothermal wells in carbonate rock in the Malm aquifer in the area of Munich/Germany can lead to significant increases in production even if less acid is used than recommended in, for example, the treatment of hydrocarbon wells. The results, however, show that the first acid treatment of a well is the most successful one, while the increases in specific capacity are lower with every further acid treatment. This indicates that the acidizing primarily removes the damage caused by the drilling process and does not generate a substantial number of new flow channels.

Moreover, about a quarter of all analyzed wells suffer from a decrease in specific capacity after continued acidizing. Although the first treatment leads to an improvement in specific capacity for all wells, subsequent treatments can result in a deterioration of the well. This seems especially true if the first acid treatment of a given well was extremely successful. The reason for this, however, is unclear and several explanations are possible.

The data show that the acidizing of geothermal wells in carbonate rock generally leads to an increase in specific capacity. However, it becomes also clear that more is not always better as continued acidizing results in only marginal improvements, and in some cases even a deterioration of the well's productivity.

Acknowledgements. This work was funded by the German Federal Ministry for the Environment, Nature Conservation, and $\mathrm{Nu}$ clear Safety (BMU) under project number 0327542A. The data were collected within the Geothermal Information System for Germany (GeotIS) project, which can be accessed for free via http:// www.geotis.de. However, site-specific data such as those on acidizing are confidential and are therefore not published within GeotIS. We thank all colleagues who provided the data that made this work possible.

The authors also thank Gioia Falcone and Wolfgang Wirth for their helpful reviews.

\section{References}

Allen, T. O. and Roberts, A. P.: Production Operations, Vol. 2, Oil \& Gas Consultants International, Inc., Tulsa, Oklahoma, 3rd Edn., 1989.

Bartels, J. and Wenderoth, F.: Numerische thermisch-hydraulische 3D-Modellierung für den Großraum München, Neubrandenburg and Berlin, 1st Edn., 2012.

Bartels, J., Wenderoth, F., Fritzer, T., Huber, B., Dussel, M., Lüschen, E., Thomas, R., and Schulz, R.: A new simulation model to evaluate interaction between neighbouring hydrogeothermal installations developing the deep Malm aquifer in the Munich region, Geophys. Res. Abstr., Vol. 14, EGU2012-9157, European Geophysical Union, 2012.

Bausch, W. M.: Der Obere Malm an der unteren Altmühl - Nebst einer Studie über das Riff-Problem, Erlanger Geologische Abhandlungen, 49, 38 pp., 1963.

Bayerisches Staatsministerium für Wirtschaft, Infrastruktur, Verkehr und Technologie, Bayerischer Geothermieatlas, 2010.

Bertleff, B. and Watzel, R.: Tiefe Aquifersysteme im südwestdeutschen Molassebecken - Eine umfassende hydrogeologische Analyse als Grundlage eines zukünftigen Quantitäts- und Qualitätsmanagements, Abhandlungen des Landesamts für Geologie, Rohstoffe und Bergbau Baden-Württemberg, 15, 75-90, 2002.

Birner, J., Fritzer, T., Jodocy, M., Savvatis, A., Schneider, M., and Stober, I.: Hydraulische Eigenschaften des Malmaquifers im Süddeutschen Molassebecken und ihre Bedeutung für die geothermische Erschließung, Zeitschrift für geologische Wissenschaften, 40, 133-156, 2012.

Böhm, F., Koch, R., Höferle, R., and Baasch, R.: Der Malm in der Geothermiebohrung Pullach Th2 - Faziesanalyse aus Spülproben (München, S-Deutschland), Geologische Blätter für Nordost-Bayern, 60, 17-49, 2010.

Böhm, F., Birner, J., Steiner, U., Koch, R., Sobott, R., Schneider, M., and Wang, A.: Tafelbankiger Dolomit in der Kernbohrung Moosburg SC4: Ein Schlüssel zum Verständnis der Zuflussraten in Geothermiebohrungen des Malmaquifers (Östliches MolasseBecken, Malm $\delta-\zeta$; Süddeutschland), Z. Geol. Wissenschaft., 39, 117-157, 2011.

Chigira, M. and Watanabe, M.: Silica precipitation behavior in a flow field with negative temperature gradients, J. Geophys. Res., 99, 15539-15548, 1994.

Duan, Z., Pang, Z., and Wang, X.: Sustainability evaluation of limestone geothermal reservoirs with extended production histories in Beijing and Tianjin, China, Geothermics, 40, 125-135, doi:10.1016/j.geothermics.2011.02.001, 2011.

Fournier, R. O. and Rowe, J. J.: The solubility of amorphous silica in water at high temperatures and high pressures, Am. Mineral., 62, 1052-1056, 1977.

Gdanski, R.: The symmetry of wormholing, E\&P, 2001.

Gdanski, R.: Advances in carbonate stimulation, Encounter and Exhibition International of the Oil Industry, College of Mexican Petroleum Engineers, 2005.

Hamill, L. and Bell, F. G.: Groundwater Resource Development, Butterworths, London, 1st Edn., 1986.

Hölting, B. and Coldewey, W. G.: Hydrogeologie, Spektrum Akademischer Verlag, Heidelberg, 2nd Edn., 2009. 
Jacob, C. E.: Drawdown test to determine effective radius of artesian well, Transactions, American Society of Civil Engineers, 112, 1047-1070, 1947.

Koch, R.: Daten zur Fazies und Diagenese von Massenkalken und ihre Extrapolation nach Süden bis unter die Nördlichen Kalkalpen, Geologische Blätter für Nordost-Bayern, 47, 117-150, 1997.

Koch, R. and Sobott, R.: Porosität in Karbonatgesteinen - Genese, Morphologie und Einfluss auf Verwitterung und Konservierungsmaßnahmen, Zeitschrift der Deutschen Gesellschaft für Geowissenschaften, 156, 33-50, doi:10.1127/1860-1804/2005/01560033, 2005.

Lund, K., Fogler, H. S., McCune, C. C., and Ault, J. W.: Acidization - II. The dissolution of calcite in hydrochloric acid, Chem. Eng. Sci., 30, 825-835, 1974.

Meyer, R. K. F. and Schmidt-Kaler, H.: Jura, in: Erläuterungen zur Geologischen Karte von Bayern 1:500.000, Bayerisches Geologisches Landesamt, München, 90-111, 1996.

Morey, G. W., Fournier, R. O., and Rowe, J. J.: The Solubility of Amorphous Silica at $25^{\circ}$ C, J. Geophys. Res., 69, 1995-2002, 1964.

Prestel, R.: Untersuchungen zur Diagenese von MalmKarbonatgesteinen und Entwicklung des Malm-Grundwassers im süddeutschen Molassebecken, Ph.D. thesis, Institut für Geologie und Paläontologie der Universität Stuttgart, 1990.

Reinhold, C.: Multiple episodes of dolomitization and dolomite recrystallization during shallow burial in Upper Jurassic shelf carbonates: eastern Swabian Alb, southern Germany, Sediment. Geol., 121, 71-95, 1998.

Rorabaugh, M. I.: Graphical and theoretical analysis of stepdrawdown test of artesian wells, Proceedings of the American Society of Civil Engineers, 79, 1-23, 1953.

Schellschmidt, R., Sanner, B., Pester, S., and Schulz, R.: Geothermal Energy Use in Germany, in: Proceedings World Geothermal Congress 2010, International Geothermal Association, 2010.
Schlichting, H. and Gersten, K.: Boundary Layer Theory, Springer, 8th Edn., 2001.

Spurk, J. H.: Fluid Mechanics, Springer, 2006.

Stober, I. and Villinger, E.: Hydraulisches Potential und Durchlässigkeit des höheren Oberjuras und des Oberen Muschelkalks unter dem baden-württembergischen Molassebecken, Jahreshefte des Geologischen Landesamts Baden-Württemberg, 37, 77-96, 1997.

Turcotte, D. L. and Schubert, G.: Geodynamics, Cambridge University Press, Cambridge, 2nd Edn., 2002.

Ungemach, P., Antics, M., and Papachristou, M.: Sustainable Geothermal Reservoir Management, in: Proceedings World Geothermal Congress 2005, International Geothermal Association, 2005.

Villinger, E.: Bemerkungen zur Verkarstung des Malms unter dem westlichen süddeutschen Molassebecken, Bulletin der Vereinigung schweizerischer Petroleum-Geologen und -Ingenieure, 54, 41-59, 1988.

Villinger, E.: Der Oberjura-Aquifer der Schwäbischen Alb und des baden-württembergischen Molassebeckens (SW-Deutschland), Tübinger Geowissenschaftliche Arbeiten, C34, 79-109, 1997.

Wolfgramm, M. and Seibt, A.: Zusammensetzung von Tiefenwässern in Deutschland und ihre Relevanz für geothermische Anlagen, in: Der Geothermiekongress 2008, GtVBundesverband Geothermie, 2008.

Wolfgramm, M., Bartels, J., Hoffmann, F., Kittl, G., Lenz, G., Seibt, P., Schulz, R., Thomas, R., and Unger, H. J.: Unterhaching geothermal well doublet: structural and hydrodynamic reservoir characteristics; Bavaria (Germany), in: Proceedings European Geothermal Congress 2007, German Geothermal Association, Berlin, 2007.

Wolfgramm, M., Obst, K., Beichel, K., Brandes, J., Koch, R., Rauppach, K., and Thorwart, K.: Produktivitätsprognosen geothermischer Aquifere in Deutschland, in: Der Geothermiekongress 2009, GtV-Bundesverband Geothermie, 2009. 